Abstracta Iranica Iranica

Revue bibliographique pour le domaine irano-aryen

Volume 25 | 2004

Comptes rendus des publications de 2002

\title{
Les chroniqueurs syriaques. Paris, L'Harmattan, 2002, appendices, index, 5 cartes.
}

\section{Christelle Jullien}

\section{(2) OpenEdition}

12 Journals

\section{Édition électronique}

URL : http://journals.openedition.org/abstractairanica/4832

DOI : 10.4000/abstractairanica.4832

ISSN : 1961-960X

Éditeur :

CNRS (UMR 7528 Mondes iraniens et indiens), Éditions de l'IFRI

\section{Édition imprimée}

Date de publication : 15 mai 2004

ISSN : 0240-8910

\section{Référence électronique}

Christelle Jullien, « Les chroniqueurs syriaques. Paris, L'Harmattan, 2002, appendices, index, 5 cartes. », Abstracta Iranica [En ligne], Volume 25 | 2004, document 236, mis en ligne le 15 mars 2006, consulté le 25 septembre 2020. URL : http://journals.openedition.org/abstractairanica/4832 ; DOI : https:// doi.org/10.4000/abstractairanica.4832

Ce document a été généré automatiquement le 25 septembre 2020.

Tous droits réservés 


\title{
Les chroniqueurs syriaques. Paris, L'Harmattan, 2002, appendices, index, 5 cartes.
}

\author{
Christelle Jullien
}

Cette étude pour grand public se divise en deux rubriques: l'une concerne les chroniques syriaques occidentales (dites jacobites), et l'autre les syro-orientales parmi lesquelles des ouvrages de langue arabe ! En préliminaire, la chronique d'Edesse et celle de Josué le stylite sont isolées. Chaque chapitre est construit sur le même modèle : biographie de l'auteur, sources de l'œuvre et résumé de la chronique. Le livre ne présente aucune histoire de la recherche, critique ou références (pourtant attendues) en notes de bas de page : il s'agit d'une première approche qui, loin d'être exhaustive, donne une vue d'ensemble sur le sujet.

\section{INDEX}

Thèmes : 6.3. Autres religions

\section{AUTEURS}

CHRISTELLE JULLIEN

CNRS - Monde iranien 